\title{
THE POTENTIAL AND LIMITS OF E-LEARNING IN CONTINUING EDUCATION OF TEACHERS
}

Iveta BEDNA ŘÍKOVÁ *, Univerzita Palackého v Olomouci, Česká republika

Přijato: 29. 4. 2016 / Akceptováno: 24. 6. 2016

Typ článku: Teoretická studie

DOI: $10.5507 /$ jtie.2016.018

Abstract: The paper deals with specific advantages, possibilities, and limitations caused by the implementation of e-learning into the lifelong programs and courses for teachers at the university. It presents experience from the supplementary pedagogical study program focused on the preparation of teachers for secondary education. The paper also deals with the problems that accompany e-learning, especially in terms of quality of the study support and attitude to the students. It emphasizes the specifics of the target group of adult learners - teachers who are already working in schools, and those, who are getting ready for their teaching career by attending the supplementary pedagogical courses.

Key words: E-learning, distance education, lifelong learning, continuing education, teachers, tutor.

\section{POTENCIÁL A LIMITY E-LEARNINGU V DALŠÍM VZDĚLÁVÁNÍ UČITEL Ů}

Abstrakt: Př́spěvek se zabývá konkrétními výhodami, možnostmi, ale i omezeními, která přináši implementace e-learningu do programů a kurzů dalšiho vzděláváni učitelù $v$ intencích celoživotniho vzdélávání na vysoké škole. Prezentuje zkušenosti z doplňujicího pedagogického studia zaměreného na př́pravu učitelu sekundárniho vzdělávání, poukazuje na problémy, které e-learning doprovází, především z hlediska kvality podpory samostudia a př́stupu ke studujicím. Poukazuje na specifika a zvláštnosti dospělých studujicich - učitelì, kteři ve školách již působi, i těch, kteři se na své učitelské působeni prostřednictvím doplňujiciho pedagogického studia teprve pripravuji.

Klíčová slova: E-learning, distanční vzdělávání, celoživotní vzdělávání, další vzdělávání, učitelé, tutor.

*Autor pro korespondenci: iveta.bednarikova@upol.cz 


\section{1 Úvod}

Aktivní účast na celoživotním vzdělávání se stala již neodmyslitelnou součástí vzdělávací nabídky téměř každé vysoké školy. Centra, střediska, pracoviště celoživotního vzdělávání (CŽV) nabízejí široké klientele, především dospělých účastníků vzdělávání, takové programy a kurzy, které vedou $\mathrm{k}$ uspokojení jejich různorodých, především profesních vzdělávacích potřeb. Specifickou cílovou skupinou v dalším vzdělávání pedagogických pracovníků, zejména na pedagogických fakultách, jsou učitelé. Jak ti, kteří v praxi již působí, tak ti, kteří se na svoje učitelské působení teprve připravují. Jde hlavně o absolventy neučitelských oborů (technických, ekonomických, prrírodovědeckých apod.), kteří hledají uplatnění ve školství. Vzhledem k pracovní vytíženosti a různým omezením je této klientele nabízena řada programů realizovaných jako distanční studium s e-learningovou podporou. Dalo by se očekávat, že by měl být o jejich vzdělávání mezi vysokoškolskými učiteli značný zájem, protože spolupráce s pracovišti CŽV nabízí profesionální působiště, ve kterém lze najít nejenom finanční efekt, ale i seberealizaci, vazbu na podmínky praxe, množství podnětů a informací a pro samotnou vysokou školu zviditelnění a nepřehlédnutelnou image. V posledních letech však klesá mezi vysokoškolskými učiteli nejenom zájem o tuto spolupráci, především o roli tutora, ale i o jakékoliv inovace a prohlubování e-learnigové podpory v těchto programech. Proč tomu tak je? Co brání vysokoškolským učitelům angažovat se v programech dalšího vzdělávání učitelů nabízených s podporou e-learnigu? Je důvodem specifičnost klientely studujících, náročnost role tutora distančního vzdělávání a e-learningu, nebo spíše nechut' a odmítavý postoj vysokoškolských učitelů v této sféře působit? Jsou vůbec distanční vzdělávání a e-learning vhodným nástrojem pro další vzdělávání učitelů? Které aspekty implementace e-learningu lze považovat za výhodu a které za spíše omezující v dalším vzdělávání učitelů? Jak získat pro působení v něm kvalitní vzdělavatele, vysokoškolské učitele-tutory, a jak je pro tuto práci motivovat? Pokusme se podrobit tyto otázky alespoň částečné analýze, abychom mohli hledat odpovědi a zvažovat možná řešení naznačených problémů.

Cílem předložené studie je představit učitele jako specifickou skupinu účastníků dalšího vzdělávání, poukázat na její zvláštnosti, argumentovat opodstatněnost e-learningu při jejich vzdělávání, současně upozornit na limity e-learningu a možnosti jejich minimalizace a kompenzace při vzdělávání učitelů, ale rovněž alespoň nastínit požadavky na vzdělavatele učitelů-tutory působící v e-learningu, včetně nezbytnosti jejich adekvátní př́pravy a motivace.

\section{Použité metody, techniky, prameny}

Pro splnění stanoveného cíle a pro získání ucelených informací a odpovědí na problémy, které jsme vytyčili jako stěžejní pro teoretické ukotvení problematiky, byla využita metoda logické analýzy jako hlavní analytická metoda sloužící kromě postupu při analýzách i k formulaci závěrů a doporučení postihujících současný stav i perspektivy očekávaného dalšího vývoje problematiky.

Pro získání podkladů dokumentujících pojímání a přistup $\mathrm{k}$ dané problematice $\mathrm{v}$ různých modelech a typech vzdělávání, jako i pro porovnání rozličných forem vzdělávání, rozdílných př́stupů, koncepcí a názorů především na sféru distančního vzdělávání a e-learningu, byla použita metoda srovnávací. 
Za účelem analýzy měnících se ekonomických a společenských podmínek, které poznamenávají život a nároky na vzdělání každého jedince, i ve vztahu k takovým jevům jako jsou rozvoj informačních a komunikačních technologií, mobilita profesí, uplatnění na trhu práce, informační exploze, demografický vývoj a další, které mění i požadavky na vzdělanost dospělých lidí, byla zvolena metoda sociologická.

Za účelem celkové orientace i hlubšího studia odborné literatury, při pořizování excerpcí, konspektů, bibliografických záznamů a citací byla použitá technika práce s odbornou literaturou.

\section{Prameny}

Studie se opírá o tuzemské i zahraniční zdroje literatury, využívá monografie, recenzované sborníky, odborné časopisy, vychází také z legislativy MŠMT ČR.

Zdrojem inspirace a poznání pro tuto studii se staly taktéž osobní zkušenosti autorky ze vzdělávací (především tutorské), metodické a manažerské práce, získané při plánování, organizaci, realizaci i evaluaci programů a kurzů distančního vzdělávání, e-learningu nebo kombinovaného studia jak v oblasti dalšího vzdělávání dospělých, tak i v terciární sfére školského vzdělávacího systému.

Ke vzniku této studie zprostředkovaně přispěli svými náměty, postřehy a připomínkami i samotní aktéŕi distančního vzdělávání a e-learningu (především tutoři, autoři, designéři kurzů, organizátoři), s nimiž měla autorka možnost spolupracovat.

\section{Další vzdělávání v kontextu celoživotního vzdělávání na vysoké škole}

Informační společnost, ve které žije dnešní člověk, přináší s sebou požadavek neustále se orientovat $\mathrm{v}$ záplavě informací, učit se a vzdělávat. Navíc rychlost, $\mathrm{s}$ jakou se ve všech oborech vyvíjejí nové poznatky, vyžaduje, aby se člověk vzdělával prakticky po celý svůj život. Efektivní rozvoj lidského potenciálu však předpokládá vytvoření bohaté a dostupné nabídky vzdělávání. Tento požadavek se týká jak formálního systému vzdělávání, tak i dalšího vzdělávání dospělých.

Vysokoškolským institucím se v tomto směru, především vlivem formulací vysokoškolského zákona č. 111/1998 Sb., § 60 (Zákon o vysokých školách), otevřelo pole působnosti zvláště na úrovni pracovišst', středisek a center celoživotního vzdělávání, která jsou zaměřena především na sféru dalšího vzdělávání, která je bezprostředně vázána na problematiku lidských zdrojů.

Další vzdělávání (angl. Continuing education) je vzdělávací proces zaměřený na poskytování vzdělávání po absolvování určitého školského vzdělávacího stupně. Zahrnuje další profesní vzdělávání, občanské vzdělávání a vzdělávání zájmové. Pojem další profesní vzdělávání označuje všechny formy profesního a odborného vzdělávání v průběhu aktivního pracovního života, po skončení odborného vzdělávání a př́pravy na povolání ve školském systému. Jeho posláním je rozvíjení postojů, znalostí a schopností vyžadovaných pro výkon určitého povolání. Má př́mou vazbu na profesní zařazení a uplatnění dospělého, a tím i na jeho ekonomickou aktivitu (Palán, 2002, s. 36).

Vysoké školy jako nejvyšší článek školské soustavy a jejich pracoviště celoživotního vzdělávání tvoří značný intelektuální rezervoár regionu, v němž působí. Termín celoživotní vzdělávání se $\mathrm{v}$ akademickém prostředí použivá $\mathrm{k}$ označení vzdělávacích aktivit vedle tradiční vysokoškolské výuky. Studijní nabídka různorodých programů a kurzů v prezenční, distanční nebo v kombinované formě nabízí širokou škálu 
př́ležitostí, jak uspokojit poptávku různých cílových skupin, především v rámci vzdělávání profesního (kvalifikačního, specializačního, rozšiřujícího, prohlubujícího vzdělávání apod.).

Jednou z cílových skupin, která se významným způsobem zapojuje do dalšího profesního vzdělávání, jsou učitelé - jak stávající učitelé (ti, kteří již ve školství působí), tak potenciální učitelé (ti, kteř́ vystudovali jiný obor a na učitelskou dráhu se teprve připravují). Jejich angažovanost v programech a kurzech dalšího vzdělávání je umocněna požadavky vyplývajícími ze Školského zákona (§2 vyhlášky č. 317/2005 Sb.), který (kromě jiného) formuluje kritéria pro tzv. pedagogickou způsobilost, neboli pro splnění kvalifikačních předpokladů v oblasti pedagogických věd.

\section{Učitelé jako specifická skupina dalšího profesního vzdělávání}

Učitelé obecně tvoří osobitou skupinu $\mathrm{v}$ dalším profesním vzdělávání. Vykazují veškeré zvláštnosti typické pro vzdělávající se dospělé, avšak i některá specifika učitelské profese, zvláště jde-li o studující, kteří učitelskou profesi již vykonávají, tudíž ve školství už působí.

\subsection{Dospělí účastníci dalšího profesního vzděláváni a jejich zvláštnosti}

Vzdělávat dospělé neboli biologicky, psychicky a především sociálně-ekonomicky zralé jedince, kteří vstoupili na trh práce (nebo do domácnosti), vyžaduje osobité př́stupy, metody, formy a pro oblast didaktiky dospělých zaškolené vzdělavatele, kteří dokážou respektovat specifika této cílové skupiny. Jedná se totiž o vzdělávání osob pracovně, časově, rodinně, společensky i jinak velice vytížených, které přistupují ke vzdělávání mnohdy se značným despektem a nedůvěrou ve vlastní schopnosti.

Dospělí se učí jinak než děti a mládež. V jejich učení sehrává velikou roli zkušenost. Široký zkušenostní základ, jejž mají, je však někdy brzdí při osvojování nových poznatků. Lze jej však využít při problémovém učení, v aplikaci na praxi, v diskusi o problémech praxe. Preferují učení, které přináší bezprostřední zisk, užitek a které jim umožní větší samostatnost, příležitost využivat různé informační zdroje, učit se různými způsoby. Dospělí vstupují do učební situace s vlastním sebehodnocením a sebevnímáním. Mají obavy, jak studium zvládnou, uvažují emocionálně. Úspěšné plnění rolí vede $u$ nich $\mathrm{k}$ pocitu sebeúcty a nezávislosti. Nejsou-li však úspěšní - ztrácejí jistotu a nedůvěřují si. V procesu vzdělávání potřebují chválit, povzbuzovat, vytvářet atmosféru tvořivosti a kooperace, partnerství. Důležitá je pro ně názornost, vizualizace problematiky, aktivní zapojení do procesu vzdělávání. Oceňují možnost diskuse a polemiky, tvưrčí řešení problémů. Učí se snáz, pokud mají dospět k porozumění než pouze k zapamatování učiva. Negativně na ně pưsobí zvyšování rychlosti při prezentaci učiva, tlak ze strany vzdělavatelů, stres a narušování průběhu učení. Učivo potřebují předkládat postupně, přehledně, v souvislostech, graficky doplněné a strukturované (obrázky, tabulky, schémata). Dospělí studující musejí znát své nedostatky, ale současně vědět, jak je odstranit. Neobejdou se proto bez zpětné vazby, sebekontroly a možnosti korigovat své chyby. Potřebují radu a pomoc, povzbuzení $\mathrm{k}$ vytrvalosti, navigaci k plánování svého učení a $\mathrm{k}$ výběru nejvhodnějších postupů.

Prusáková $(2000$, s. 4) upozorňuje na to, že dospělí mají odlišné cesty vzdělávání, na základě kterých si vytvořili rozličné styly učení. Mnozí dokonce s odstupem času 
nedokáží pracovat $\mathrm{s}$ literaturou, i když jim to kdysi nečinilo problémy. Najít vlastní efektivní styl učení může pro ně znamenat překonání velkého problému.

Styly učení, jak uvádí Hartl (1999, s. 104), hrají v dospělosti důležitou roli. Různá učební prostředí vyžadují různé učební styly. Na druhé straně nelze předpokládat, že každý dokáže prrizpůsobit své učební styly jakémukoli učebnímu prostředí.

Problematikou učebních stylů se kromě zmíněného Hartla (1999) zabývá podrobněji především Mareš (1998), a v souvislosti s e-learningem např. Barešová (2003) a Šimonová, Poulová (2012).

Shrnující pohled na učení dospělých prezentuje v 8 principech J. R. Moore (1988):

1. Učení závisí na motivaci.

2. Učení závisí na schopnosti učit se.

3. Učení závisí na předchozích zkušenostech.

4. Učení závisí na osobní angažovanosti a zájmech učících se.

5. Učení závisí na prostředí, ve kterém probíhá (bezpečí, pohodlí, respektování hygienických, ergonomických požadavků apod.).

6. Učení je efektivnější, řídí-li si jeho průběh učící se sami.

7. Učení je efektivní, má-li praktický charakter a zaměření na řešení problémů.

8. Učení je efektivnější, vyhovuje-li učebnímu stylu učících se.

\section{Sociální kontext učení dospělých}

Proces učení dospělých ovlivňuje rovněž sociální prostředí, v němž se učení uskutečňuje. Vzájemné působení vzdělavatele a účastníků, ale také účastníků mezi sebou, průběh této sociální interakce, vztahy, které se utvářejí ve skupině, chování a vlastnosti všech účastníků vzdělávání, to vše vytváří tzv. sociální klima. Má-li být toto klima př́iznivé, takové, které podporuje učení a vzájemnou spolupráci mezi účastníky a tím přispívá $\mathrm{k}$ efektivitě učení, musí být $\mathrm{k}$ tomu náležitě disponován i samotný vzdělavatel. Od jeho schopnosti vytvářet dobré mezilidské vztahy, dešifrovat těžkosti a problémy studujících, od jeho dovednosti objektivní sociální percepce účastníků vzdělávání, od typu převažujících interakcí ve skupině (individualistická, soutěživá, kooperativní), které podporuje, závisí jeho úspěšnost při vzdělavatelské práci s dospělými.

Odborníci na vzdělávání dospělých (Bočková, 2002; Hartl, 1999; Petřková, 2000; Prusáková, 2000), se shodují v názoru, že těžiště vzdělávání dospělých spočívá v kooperativním učení, které je charakteristické povzbuzováním pozitivních vztahů mezi účastníky, otevřenou, efektivní komunikací, podněcováním zájmů účastníků, rovnocenným postavením členů skupiny a povzbuzováním jejich samostatného myšlení.

Ve vzdělávací práci $\mathrm{s}$ dospělými náleží dominantní postavení tzv. evalvačnímu jednání, které vychází z požadavku respektovat v komunikaci a interakci s dospělými úctu a vážnost. Toto jednání je založené na povzbuzování, chválení, zdůrazňování úspěchů, pozitiv a kladných stránek osobnosti dospělého účastníka vzdělávání. Naproti tomu devalvační způsob komunikace projevující se ponižováním, ironizováním či mechanickým přenášením edukačních metod $\mathrm{z}$ výchovy a vzdělávání dětí a mládeže do prostředí dospělých snižuje motivaci účastníkủ i efektivitu tohoto vzdělávání. Nelze jej ve vzdělávání dospělých tolerovat. 
Vzdělávání dospělých tudíž vyžaduje profesionální př́stup kvalifikovaných vzdělavatelů - učitelů, lektorů, tutorů, mentorů, instruktorů, trenérů, koučů, bez ohledu na to, jakým termínem je označujeme.

\subsection{Učitelé a specifika jejich vzdělávání}

Poněkud svérázným př́stupem ke vzdělávání se vyznačují učitelé, kteří aktivně ve školství působí. Tím, že se sami ve své práci vzděláváním zabývají, mají častokrát pocit, že o vzdělávání vše vědí, a proto často podceňují pedagogickou teorii. Naše mnohaleté zkušenosti z pedagogického vzdělávání učitelů sekundárního vzdělávání (z doplňujícího pedagogického studia) jsou dokladem toho, že preferují především face to face výuku a možnost účastnit se jí především o víkendech. Vzhledem $k$ tomu, že je uvolňování z práce pro učitele většinou problematické a jejich zaměstnavatelé (ředitelé škol) odmítají řešit jejich nepřitomnost (z důvodu vzdělávání) suplováním, vybírají si z nabídek vysokých škol především programy realizované jako distanční vzdělávání. Mnohdy však nemají vůbec představu, co takové vzdělávání obnáší. Ačkoliv se jim zamlouvá minimální fyzický kontakt se vzdělavateli, omezený na tutoriály a účast na zkoušce, problémem pro ně je samostudium, príprava na tutoriály a požadavek plnit v termínu požadované úkoly. Přitom právě distanční vzdělávání (v našich podmínkách s podporou e-learningu) nabízí učitelům veškeré vymoženosti pro flexibilní a na podpoře studujícího založeného vzdělávání.

\section{Potenciál distančního vzdělávání a e-learningu pro vzdělávání učitelů}

Podívejme se nyní na možnosti, kapacitu neboli potenciál distančního vzdělávání a e-learningu a identifikujme jejich konkrétní výhody, pozitiva $\mathrm{v}$ dalším profesním vzdělávání učitelů, abychom dokázali argumentovat vhodnost jejich výběru.

Distanční studium vzniklo jako ucelený soubor vzdělávacích principů a pravidel, které umožňují studovat (vzdělávat se) člověku souběžně s plnou ekonomickou i společenskou aktivitou a prakticky nezávisle na reálné vzdálenosti mezi místem jeho bydliště či pracoviště a sídlem vzdělávací instituce. Jedná se o vzdělávání založené na samostudiu, ve kterém jsou studující a vyučující fyzicky odděleni. Využívá multimédia, zejména komunikační prostředky, kterými lze prezentovat učivo - tištěné materiály, magnetofonové záznamy, videozáznamy, počítačové programy, programy v sítích, TV přenosy apod., pro komunikaci se studenty pak zejména telefony a e-mail. Zmíněnými studijními materiály (oporami) a celkovým organizačním zajištěním studia orientovaného na potřeby studujícího-klienta se instituce nabízející distanční vzdělávání snaží vykompenzovat nevýhody této formy vzdělávání. Distanční vzdělávání tudíž vychází a reaguje na specifické podmínky studujících, ke kterým patří geografická vzdálenost a izolace studujících, omezený čas pro studium a fakt, že styk s vyučujícím je zde zúžený na minimum. Vývoj distančního vzdělávání již od prvopočátku sledoval zájmy a potřeby, možnosti a omezení především klientely zaměstnaných dospělých, kteří byli nuceni $\mathrm{z}$ různých důvodů si doplňovat, zvyšovat, prohlubovat či jinak rozvíjet své vzdělání.

Významné postavení zaujímá v distančním vzdělávání e-learning. Podle Zlámalové (2012, s. 35) představuje e-learning naprosto nezbytnou technologickou oporu distančního vzdělávání, která umožňuje jak efektivní komunikaci vzdělávaného se vzdělavatelem, tak účinnou administraci a rrízení studia. Předností e-learningu je rovněž možnost vytvářet kvalitní hypertextové studijní opory s možností širokého využití audio 
či videoprvků, animací apod. To vše, včetně možnosti průběžného a závěrečného hodnocení výsledků samostatného studia (autoevaluační testy, zkouškové online testy), považuje zmíněná autorka za významný pedagogický aspekt. Nelze než souhlasit s jejím přesvědčením, které zmiňuje dále (tamtéž, s. 36), že distanční forma vzdělávání (bez ohledu na to, v jakém úseku CŽV nebo učení je použita) je v současnosti ukotvena na možnosti efektivního využití e-learningu.

Podobně uvažuje i Burgerová (2012), která poukazuje na to, že pokud se e-learning propojuje s distanční formou výuky s využitím širokého spektra technologií ke komunikaci, jde z hlediska úspory lidských zdrojů a času o jeden z nejzajímavějších a nejefektivnějších způsobů vzdělávání.

Jsou-li distanční vzdělávání a e-learning připravovány a realizovány kvalitně, s následnou evaluací a akceptací jejich závěrů, disponuje-li vzdělávací zařízení škálou podpory studujících včetně kompetentního tutorského zázemí, můžeme $\mathrm{v}$ něm identifikovat řadu výhod a předností, které vycházejí z jejich samotného pojetí.

\section{Samostudium jako výhoda}

$\mathrm{V}$ dnešní uspěchané až hektické době se jakékoliv studium zasahující do pracovního procesu a vytrhující zaměstnance z práce stává spíše luxusem. Mnoho zaměstnavatelů i v rámci profesního vzdělávání hledá cesty jak na pracovišti minimalizovat fyzickou neprítomnost svých zaměstnanců, kteří se účastní různých školení a kurzi̊ pořádaných prezenčně. Proto vzdělavatelé všemožně hledají cesty, jak vzdělávat bez narušení pracovního procesu. V tom mají distanční vzdělávání a e-learning neoddiskutovatelnou prioritu. Umožňují frekventantům studovat při zaměstnání, ale v době, kdy je to pro ně samotné vhodné, a tak, aby jejich studium bylo usměrňováno a řízeno s maximálním komfortem a podporou.

Ne náhodou nachází tyto způsoby vzdělávání své př́iznivce právě $\mathrm{v}$ řadách učitelů, kteří jsou typickou cílovou skupinou se všemi atributy omezujícími přímé vzdělávání. Jejich fyzická svázanost s pracovištěm (školou, výukovým procesem, rozvrhem apod.), nemožnost se kdykoliv uvolnit či nechat zastoupit, pracovní vytíženost, mimoškolní aktivity a často i společenská angažovanost na jedné straně a oprávněné požadavky zaměstnavatele, zrrizovatele či vlastní potřeba se vzdělávat na straně druhé způsobuje rozpor, který musí řešit. Rezultát v podobě distančního vzdělávání či e-learningu je často jedinou pro obě strany prijiatelnou variantou.

\section{Didakticky zpracované učivo, aktivita a zpětná vazba - jednoznačné plus}

Distanční vzdělávání a e-learning však nenabízí pouze časovou flexibilitu, ale i didakticky propracované učivo (členěné do menších logických celků), které umožňuje volit si vlastní tempo i specifický styl učení a současně kontrolovat vlastní pokroky ve studiu. To je velká výhoda oproti př́mé výuce. Jde o systém kroků, které studující usměrňují, vedou je $\mathrm{k}$ cíli a regulují jejich samostudium. Každou učební dávku mají možnost si procvičit, promyslet a vnitřně zpracovat tak, aby ji následně využili při řešení praktických úloh. Aktivita a zpětná vazba je zde základem samostudia a motivace dominantním činitelem vedení a komunikace ze strany autora. At' se již jedná o jakýkoliv typ studijního materiálu, jejž studující využívají, důsledné didaktické zpracování a promyšlená grafická úprava je v něm samožrejmostí. Přiměřená obsažnost, logická 
struktura, atraktivita předkládaného učiva, informací a celková přitažlivost zvyšují účinnost takto řizeného sebevzdělávání na maximum.

\section{Fyzické oddělení studujících od vzdělavatelů jako výhoda}

Ač by se tato skutečnost mohla považovat více za nevýhodu, podívejme se na tento problém z té druhé, lepší strany. To, že účastník vzdělávání může být vzdálen od vzdělávací instituce, v níž realizuje své vzdělávání stovky, dokonce i tisíce kilometrů, umožňuje vzdělávacímu zařízení oslovit potenciální klientelu nejenom v regionu, v němž působí, ale dokonce v celorepublikovém či mezinárodním měřítku. Klientovi (učiteli) to zase umožňuje zvolit si takovou instituci nebo typ vzdělávání, který mu vyhovuje, bez ohledu na to, $v$ jaké je vzdálenosti či dostupnosti.

Fakt, že fyzická př́tomnost je $\mathrm{v}$ distančním vzdělávání omezena na minimum, šetří čas a cestovní výlohy jak frekventantům samotným, tak vzdělavatelům, snižuje výdej financí za pronájmy učeben a mzdy zajištujícího personálu, řeší problémy s ubytovací kapacitou, minimalizuje náklady na provoz apod.

Pro studující to také znamená jistou nezávislost a mobilitu. Má-li poskytovatel vzdělávání kromě e-mailové komunikace možnost využívat e-learningovou podporu, především LMS (Learning Management System), který plní požadavky na vytvoření virtuálního výukového prostředí a slouží $\mathrm{k}$ řízení a vyhodnocování procesu vzdělávání, stává se studium navíc uživatelsky komfortnější.

\section{Multimédiálnost učení a komunikace - jednoznačné pozitivum}

Skutečnost, že distanční vzdělávání v největší možné míře využívá multimédia jak pro prezentaci učiva, poznatků a informací prostřednictvím různých studijních opor (tištěné texty, audionahrávky, videopořady, interaktivní programy na $\mathrm{CD}$, v sítích, Internet, Intranet, televizní, rozhlasové pořady, videokonference apod.), tak pro komunikaci se studujícími, umožňuje plnohodnotně reagovat na jejich potřeby. Jedná se hlavně o zvýšení účinnosti učení, o nahrazení chybějícího sociálního kontaktu, ale i kompenzaci chybějící atmosféry (z přímé výuky).

Velice efektivním prostředkem $\mathrm{v}$ tomto směru je především e-learning, nabízející studujícím veškeré výhody multimediálního zpracování studijních opor, kurzů a celých programů, interaktivitu, vizualizaci, bezprostřední zpětnou vazbu a průběžnou kontrolu znalostí, možnost neomezené aktualizace, doplňování a rozšiřování informací, ale i komunikaci studujících navzájem (napřr. prostř̌ednictvím diskusních skupin, nástěnek, chatu). Multimediální učení také lépe využívá lidské smysly a tím zvyšuje efektivitu vzdělávání. Možnost zapojení vizuální, auditivní složky i vlastní aktivity do procesu učení je pro dospělé účastníky indikátorem stoupající míry osvojení poznatků a tím i úspěchu ve studiu.

Pro vzdělávání dospělých jednoznačně platí následující pravidlo: Slyším a zapomenu, vidím a vzpomenu si, jednám a osvojím si. Proto je pro učení se dospělých tolik důležitá vizualizace (optické informace jsou rychleji vnímány a naučeny, ale i pevněji v paměti udržovány), aktivní participace (zejména využívání předchozí zkušenosti a tvưrčího myšlení), opakování a kódování informací (tvorba asociací a obrazových představ), která zvyšuje podíl informací uložených do dlouhodobé paměti. To vše multimediálnost v e-learningu umožňuje. 
Učitelské vzdělávání vyžaduje kromě osvojení náležité pedagogické a didaktické teorie rovněž propojení s praxí, prezentaci učiva spojenou s náhledem do problematiky školního dění, zprostředkování situací z reálné nebo simulované výuky, prezentaci virtuálních hospitací, problémových př́ípadů a jevů. To vše lze prostřednictvím e-learningu do procesu vzdělávání implementovat a zvýšit tak nejenom jeho didaktickou účinnost, ale i atraktivitu a zajímavost.

\section{Podpora studujících}

Přestože dospělí a především učitelé vykazují větší samostatnost v rrízení sebe sama při učení, jsou schopni stanovovat si cíle svého učení, využívat různé informační zdroje, učit se různými způsoby, nežrídka potřebují i radu a pomoc. Tu jim zajištuje tutor i celý systém organizace distančního vzdělávání, včetně poradenství a individuálního řešení problémů. Možnost posouvat termíny pro splnění konkrétních požadavků, skládat programy tzv. šité na míru, morální podpora ze strany všech zainteresovaných, to vše je v distančním vzdělávání (i s podporou e-learningu) základem klientského př́stupu.

Všichni pracovníci jsou vedeni k efektivní všestranné komunikaci se studujícími, ke kompetentnímu rozhodování a komfortnímu servisu služeb. Vysoká dostupnost informací a četnost komunikace dovolují téměř neomezené kontakty s personálem vzdělávací instituce, jejíž hlavní zásada by se měla nést v duchu hesla „pomoci všem, kteří se chtějí vzdělávat, aby studium úspěšně zvládli“. Distanční studium je tudíž založeno na takovém př́stupu vzdělavatelů ke studujícím, který minimalizuje snížení sebedůvěry studujících a všemožně mobilizuje jejich vzdělávací úsilí.

\section{Didaktický rozměr e-learningu a místo učitele (tutora) v něm}

Ohlédneme-li se za výčtem prezentovaných možností distančního vzdělávání a e-learningu, jistě nám neunikne, že je e-learningová podpora pro učení dospělých nesmírně důležitá. Samotný e-learning a jeho implementace do distančního vzdělávání má význam především pro vzdělávání učitelů. Čím větší prostor e-learning v tomto vzdělávání pokrývá, tím více lze očekávat úspěšnost učení této cílové skupiny. V čem ještě se skrývá potenciál e-learningu?

Přes různorodost definic a pojetí e-learningu, které lze $\mathrm{v}$ odborné literatuře identifikovat, se v poslední době chápe e-learning především jako vzdělávací proces využívající informační a komunikační technologie, prostřednictvím kterých lze funkčně použít širokou škálu didaktických metod pro zvýšení efektivity učení. Prioritou v e-learningu začínají být pedagogické a andragogické prŕstupy se zaměřením na osobnost učícího se, akcentující měnící se úlohy učitele.

Pedagogický príistup pojímá e-learning jako vzdělávací proces, ve kterém jsou využívány informační a komunikační technologie. Akcentuje pedagogicko-didaktické aspekty e-learningu se zaměřením na studující, vzdělávací obsah, cíle, vzdělávací strategie, vzdělávací potřeby a vzdělávací prostředí. Zahrnuje i takové pedagogické aspekty, jakými jsou motivace, aktivizace, evaluace apod. (Egerová, 2012, s. 28).

$\mathrm{V}$ tradiční výuce face-to-face je učitel prostředníkem mezi učivem a studujícími. Má možnost rozhodnout, které obsahy jsou pro studující důležité, vybrat učebnice, doporučit literaturu z knihovny, věnovat více času určité problematice či tématu dle svého uvážení apod. Mohlo by se zdát, že díky e-learningu se tento prostor učitele zužuje, že již není prř́mým poskytovatelem informací a poznání. Tuto úlohu přebírají a suplují autoři kurzio, 
studijních opor, multimediálních vzdělávacích objektů. Na druhé straně je však vzdělavatelské působení učitelů mnohem významnější. Poskytují sice studujícím mnohem méně informací o učivu, ale o to více jim musí pomáhat v procesu jejich učení, navigovat je správným směrem př̀i vyhledávání, třídění a zpracovávání informací, při používání zdrojů z internetu a webových stránek, při utváření názorů a postojů. Zde dochází ke značnému posunu interakcí mezi učitelem a studujícím v intencích on-line komunit, v nichž se učitel dostává více do role facilitátora (Hughes, 2009, s. 53).

Je zřejmé, že e-learning, má-li být efektivní, vyžaduje ke své realizaci speciální didaktické př́ístupy, metody. Ty se díky podpoře ICT neustále vyvíjejí a jak ukazují zkušenosti (napřr. z posledních ročníkủ soutěže eLearning v Hradci Králové nebo konferencí ONLINE EDUCA Berlin), v e-learningu dochází k výraznému posunu od instruktivního ke konstruktivnímu př́ístupu. Studující již není pouze instruovaný a řízený, ale stále častěji se musí do procesu učení zapojovat, konstruovat si své znalosti sám. K tomu mu pomáhají multimediálně zpracované studijní materiály, kurzy využívající interaktivní simulace reálných jevů umožňující i emotivní prožitky a především prostor pro kritické myšlení. To je podporováno učitelem-tutorem.

Konstruktivismus v e-learningu však vyžaduje od učitele-tutora poněkud jiné role a kompetence. Učitel se stává více průvodcem studujícího, facilitátorem, poradcem a navigátorem, hodnotitelem průběžných výsledků, ale především motivátorem, moderátorem virtuálních kontaktů, skupinové diskuse a kooperace. Podobně jako v klasickém distančním vzdělávání zastává spiše funkci „kouče“ a hodnotitele samostatných prací, který navíc efektivní komunikací usměrňuje proces učení.

Veškerá uvedená doporučení a celkový didaktický rozměr e-learningu podtrhují následující slova: „Aby byl e-learning úspěšný, nesmí být budoucí prioritou rozvoj e-learningových technologií a platforem (typu LMS, WBT), ale vývoj a zlepšování procesů řízeného sebeučení (např. inteligent learning proceses), zlepšování kvality vědomostní báze (učební texty, multimedializace, interakce), využití př́stupů konstruktivismu. Sebelepší e-learningové prostředí nenahradí kvalitní multimedializovaný distanční text a efektivní proces motivujícího a motivovaného vzdělávání“ (Kopecký, 2006, s. 111).

Z toho, co jsme uvedli, jednoznačně vyplývá, že e-learning může být při promyšlené struktuře kurzů a při respektování všech didaktických zásad a požadavků na vedení studujících vhodným nástrojem efektivního vzdělávání. Jeho designéři, technologové, autoři, scénáristé, metodici, tutoři a další aktéri by si však měli uvědomit, že pouze atraktivita a multimedialita (ačkoliv je její přínos nezpochybnitelný) nestačí, ale že především pedagogická funkčnost je klíčovým parametrem pro posuzování e-learningu.

\subsection{Tutor v distančním vzdělávání s podporou e-learningu}

Je-li distanční vzdělávání nebo jeho část realizovaná s podporou e-learningu, předpokládá to rovněž specifické postavení a aktivity $\mathrm{v}$ práci tutora, který však musí být na tyto změny předem připravený. Tato adaptace nemusí být nijak dramatická, pokud je tutor vnitřně přesvědčený o funkčnosti a efektivitě využívání ICT ve vzdělávání, je dostatečně motivovaný a jeho technické dovednosti odpovídají nárokům na něj kladeným.

Kromě pravidel a postupů běžně použivaných v distančním vzdělávání se totiž tutor ve virtuálním prostředí musí vyrovnat především s náročnými požadavky na technické 
zvládnutí a efektivní využivání dostupných nástrojů pro on-line komunikaci, které umožňují všestrannou podporu spolupráce v síti, výměnu názorů a studijních zkušeností, jako i aktivní zapojení se do procesu řízeného učení.

Učitelé plní v e-learningu klíčovou úlohu. Výzkumy poukazují na to, že silná učitelská podpora, vysoká frekvence kontaktů, interakce se studenty a vynikající organizační schopnosti jsou důležité prvky úspěšného online kolaborativního učení (Hughes, 2009, s. 52).

Dovednost komunikace $\mathrm{v}$ on-line vzdělávání (schopnost připravit diskusi, ř́́dit setkání a chat v on-line, aktivně naslouchat, klást dotazy, hodnotit diskusi) a motivovat studující (rozvíjet konstruktivní vztahy, diagnostikovat potřebu pomoci, podporovat pokroky ve studiu, poskytovat zpětnou vazbu a přátelský př́stup k hodnocení) - to vše je podle Egera $(2002$, s. 59) nezbytné v tutorské práci rozvíjet.

Umění ř́ídit elektronické vzdělávání a podílet se na jeho př́ípravě a tvorbě může být významným prostředkem motivace studujících. Tutor jako aktér e-learningu plní v tomto typu vzdělávání své specifické a nezastupitelné úkoly. At' se již jedná o off-line výuku (prostřednictvím e-mailu, diskusních skupin, nástěnek) nebo on-line (pomocí textové komunikace chat, sdílení aplikací, audio a videokonferencí, virtuálních trríd apod.), je jeho hlavním posláním podporovat studující v jejich učení. Předpokladem úspěšného zvládnutí tohoto úkolu je působení tutora jako povzbuzovatele, motivátora, poradce.

Učiteli náleží v on-line vzdělávání úloha osoby podporující učícího se, která má jistou odpovědnost za dosažení odpovídajících vzdělávacích standardů. Protože se stává také moderátorem diskusí řízených studenty, měl by plnit tři základní role: organizační, sociální a intelektuální. V procesu on-line vzdělávání se výrazně mění osoba učícího se, který se musí ztotožnit s novou rolí, odlišnou od té, která mu náležela v rámci tradiční edukační kultury. Nyní se musí naučit týmové spolupráci, př̌ijmout odpovědnost za svoje vzdělávání, spolupodílet se na prŕpravě programů, kurzi̊ a jejich modifikaci. Tento jedinec se stává členem společnosti učících se a přijímá i odpovědnost za proces učení celé skupiny v sociálním kontextu procesu moderního vzdělávání (Švejda, 2007, s. 462-463).

Aby bylo působení tutora pedagogicky efektivní, mělo by zahrnovat co nejvíce elementů posilujících motivaci, nabízejících studentům pozitivní emoce nezbytné pro mobilizaci jejich učebního nadšení, stimulujících jejich zájem, pozornost, trpělivost a vytrvalost v procesu učení.

\section{Limity e-learningu ve vzdělávání učitelů}

Vzdělávání učitelů, tak jak jej vnímáme z vlastní manažerské a tutorské praxe při pedagogickém vzdělávání v kontextu celoživotního vzdělávání na Pedagogické fakultě Univerzity Palackého v Olomouci, má však i jisté limity. Ty lze zařadit jak na stranu samotných účastníků, tak na stranu tutorů.

\subsection{Limity na straně účastníků Heterogennost účastníků}

Účastníky našich programů zaměřených na vzdělávání učitelů druhého stupně základních a stř̌edních škol jsou jak učitelé již ve školách působící (avšak bez náležité kvalifikace a patřičného zařazení), tak ti, kteří vystudovali vysokou školu většinou technického, ekonomického nebo prírodovědného směru a na učitelskou dráhu se teprve 
připravují. Stále častěji se ke studiu hlásí dospělí vyšších věkových kategorií, kteří se rozhodují pro učitelskou profesi po dlouhé podnikové nebo firemní praxi v oboru, který vystudovali. K frekventantům patří též ženy (vysokoškolačky) na rodičovské dovolené a čerství absolventi neučitelských oborů usilující o zvýšení si šancí na trhu práce. Pro tak nesourodou skupinu je velice obtížné vytvořit univerzální e-learningový produkt, blízký jejich vstupním předpokladům, nacházet vhodné prríklady, školní situace, diagnostikovat styly a preference $\mathrm{v}$ jejich učení, usměrňovat jejich samostudium a podporovat komunikaci.

Řešení v tomto směru nabízí Kopecký (2006, s. 83-84), který zdůrazňuje ve-learningu tzv. inteligentní procesy učení. Ty jsou výsledkem individualizace učebních cílů a vzdělávacích procesů. $\mathrm{V}$ praxi to znamená, že každý studující může ke stejnému cíli postupovat $\mathrm{v}$ procesu učení různými cestami. E-learningový obsah se pak přizpůsobuje studujícím dle informací, které o nich získají sami vzdělavatelé (tutoři, manažeři studia apod.). Personalizovaný inteligentní ř́dicí systém upraví učivo dle potřeb studujících (naprííklad podle stylu učení). Studující na vyšší úrovni neuvidí některé triviální části disciplíny, naopak se jim zobrazí složitější učivo a v závislosti na tom také verifikační aparát. Systém lze modifikovat pomocí různých SCO (Shareable Content Object) objektů - sdílejících obsah.

Jaké finanční nároky tato personalizace vyžaduje, není zřejmé. Ale vzhledem $\mathrm{k}$ tomu, že v našem vzdělávání e-learningu náleží pouze podpůrná funkce, můžeme toto řešení v současné době považovat pouze za ,zbožné prání“.

\section{Odpor k využívání technologií}

Ačkoliv nelze jednoznačně říct, že všichni účastníci dalšího vzdělávání učitelů mají negativní vztah $\mathrm{k}$ ICT, nechut' a často i indispozice je využívat je mnohdy až překvapující. Ani po úvodním zaškolení pro práci s LMS nejsou někteří účastníci schopni odeslat úkol, reagovat na dotaz nebo vyplnit si v systému údaje o sobě. Vložit do LMS vlastní fotografii je i po instruktáži pro mnohé nadlidský výkon. Důvodem těchto potíži může být i nedostatečné softwarové vybavení PC našich účastníků, ačkoliv jsou na tyto požadované technické předpoklady studia předem upozorněni.

Lze pouze doufat, že tento problém vyřeší v nejbližší budoucnosti př́liv nové vlny účastníků našich programů z řad současné mladé generace ,počítačových maniaků“, kterou Prensky (2001) velice výstižně nazývá „Digital Natives“ neboli „digitální domorodci“. Do té doby nezbývá realizátorům a tutorům nic jiného než trpělivě vysvětlovat a identifikované nedostatky řešit.

\section{Neochota virtuálních kontaktů}

Tím, že učení v e-learningu probíhá nezávisle na učitelích, geografické vzdálenosti a čase, může učící se sociálně izolovat, deprimovat, zvláště ty, kteří se vyhýbají virtuální komunikaci. Přestože učitelé patří ke skupině dospělých účastníků, kteř́i preferují a vyhledávají komunikaci a sociální kontakty, obecně se velice neradi zapojují do virtuální, především on-line komunikace. Mnohem ochotněji participují na diskusích v rámci tutoriálů a účastní se praktické výuky a cvičení.

Důvodem této neochoty mohou být již zmíněné nedostatečné technické dovednosti, tak i nezbytnost být $\mathrm{v}$ danou dobu dostupný on-line. Vzhledem k pracovní a časové vytíženosti jak účastníků, tak i tutorů jsou totiž tyto kontakty omezeny na večerní 
a víkendové hodiny. Domluvit společný den a čas bývá velice složité. Proto se komunikace omezuje především na off-line kontakty, telefonování a e-mail.

Podobnou zkušenost jsme zaznamenali při tutorské práci $\mathrm{v}$ rámci pilotního elektronického kurzu VZEDOS (Systém vzdělávání vzdělavatelů dospělých), jehož účastníky byli především profesionální vzdělavatelé, hlavně učitelé různých typů škol. Ze zkušeností, které jsme prezentovaly na konferenci eLearning 2007 (Zlámalová, Bednaříková, 2007, s. 490-498) jednoznačně vyplynulo, že kategorie účastníků, jejíž hlavní doménou je vzdělávání, výuka a práce s lidmi, může mít s komunikací v e-learningovém prostředí potíže.

Zmíněného pilotního on-line kurzu, který probíhal v LMS Moodle, se účastnilo 26 účastníků (24 z nich studium úspěšně dokončilo), především profesionálních vzdělavatelů, působících na středních odborných školách, VOŠ, ale i v terciární sfére. Cílem kurzu bylo proškolit první skupinu studujících (pro oblast vzdělávání dospělých), získat poznatky o kvalitě obsahu kurzu a použitých metodách, ale i zpětnou vazbu $\mathrm{z}$ tutorské práce $\mathrm{s}$ danou cílovou skupinou, identifikovat možnosti a dovednosti studujících pro e-learningovou formu studia. Studijní obsah byl rozdělen do 6 studijních kapitol. Každá kapitola představovala samostatnou studijní jednotku se všemi metodickými prvky podporujícími samostudium. K jeho účinnosti přispívali a interaktivní komunikaci řídili dva tutoři. Celková studijní zátěž byla plánována na cca 140 hodin, včetně třech prezenčních tutoriálů, zpracování třech korespondenčních úkolů (POTů) a vypracování závěrečné písemné práce, která byla na závěrečném tutoriálu obhajována před odbornou komisí. Postřehy z tutorské práce poukázaly, kromě jiného, i na problém nezájmu studujících o účast v diskusním prostředí, ačkoliv na prezenčních tutoriálech byla diskuse velice živá a podnětná. V elektronickém prostředí se projevovala pouze malá část studujících. Přitom řada účastníků velice intenzivně využívala př́mou e-mailovou komunikaci s tutorem mimo elektronické prostředí Moodlu.

\section{Nedostatečné samostudium}

Ačkoliv lze samostudium považovat za jistou výhodu e-learningu, tak jak jsme uvedli dříve, nezbytnost mobilizovat vlastní osobnost, vlastní vzdělávací úsilí ke studiu samotnému, $\mathrm{k}$ adekvátní př́pravě, zvláště na tutoriál, je již dlouhá léta mezi tutory diskutovaným problémem distančního vzdělávání a e-learningu.

Je zajímavé, že i u účastníků-učitelů, kteří jsou zvyklí zadávat a kontrolovat domácí úlohy svých žáků, je vlastní studijní př́íprava, především na tutoriál, podceňována a někdy i sabotována. Vzhledem $\mathrm{k}$ tomu, že tutoriály v doplňujícím pedagogickém studiu mají převážně aplikační a praktický charakter, je účastníkům neustále zdůrazňováno, aby přišli na tutoriály teoreticky předem připraveni. Tento požadavek naráži na mylnou představu a domněnku účastníků, že tutor bude přednášet, nebo se jinak k objasňování teorie vracet. Očekávání účastníků (i když jde o učitele), že prezenční setkání (tutoriál) bude probíhat ve formě klasické prezenční výuky, i v př́ípadě existence profesionálně zpracovaných studijních opor, je pro vzdělavatelskou práci velkým rébusem. Podobný problém zaznamenáváme opakovaně i při zpracovávání samostatných prací a úkolů, jejichž úroveň závisí především od kvality samostudia. 


\subsection{Limity na straně tutorů}

\section{Nezájem o práci tutora}

Doplňující pedagogické studium zaměřené na př́pravu učitelů 2. stupně ZŠ a SŠ patří v poslední době $\mathrm{k}$ velice vyhledávaným programům celoživotního vzdělávání, která CCV PdF UP v Olomouci nabízí. Zvláště v posledních letech, kdy nastal díky „liteře zákona“ obrovský boom po zvyšování kvalifikace v oblasti pedagogických věd, jsme nebyli schopni dostatečně uspokojit narůstající poptávku. Jedním z důvodů byl především nedostatek kvalitních tutorů. Ačkoliv jsme se při oslovování vhodných vzdělavatelů z řad vysokoškolských učitelů snažili vyvolat zájem a motivovat potenciální tutory solidním finančním ohodnocení, informace o tom, že jde o e-learning, víkendové tutoriály a řízení samostudia s požadavkem náležitého vedení a opravování úkolů, obdrželi jsme pokaždé stejnou reakci: odmítnutí, nezájem. Obavy z technické náročnosti, z množství hodin „,prosezených u počítače“, představa, že k úvazku přibude ještě další s horrorovým označením „e-learning“, to jsou časté důvody odporu a zpochybňování didaktické účinnosti tohoto vzdělávání.

Důvodem nezájmu o působení na pozici tutora je rovněž $\mathrm{v}$ akademickém prostředí prosazovaná preference aktivit přinášejících započitatelné „body“, která pochopitelně odsunuje tutorství na „vedlejší kolej“. K neméně důležitým aspektům preferovaného nezájmu o činnost tutora patř́ absence motivace vysokoškolských učitelů $\mathrm{k}$ této práci ze strany nadřízených i instituce samotné.

\section{Nedostatečná motivace studujících ze strany tutora}

Působení učitele-tutora je pro motivaci v e-learningu nesmírně důležité, protože osamocenost studujících snižuje efektivitu učení. Studenti ve-learningu musí být $v$ kontaktu s tutory i spolužáky. Tato spolupráce by měla být náležitě rozvíjena různými metodami (diskusními, problémovými, simulačními, kritického myšlení, spolupráci na úkolech apod.). Studujícím nesmí chybět rychlá zpětná vazba při komunikaci i komentování úkolů, možnost kooperace, participace. Učitel-tutor se v e-learningu stává „navigátorem“, který vede aktivní studenty džunglí nabízených informací, „evaluátorem“, který hodnotí výsledky učení, „moderátorem“, který usměrňuje a koordinuje vzájemné interakce účastníků studia, ,aplikátorem“, který by se měl snažit zapojit studenty do vlastního problému v oblasti teoretických i praktických aplikací studované disciplíny.

Tutor musí být velice citlivý při řešení problémů studujících. Měl by být schopen eliminovat veškeré úzkosti, strach se selhání u studujících, působit na ně především podnětně, povzbudivě, posilovat jejich sebevědomí a důvěru ve vlastní schopnosti. Má-li ke studujícím výhrady a připomínky, měl by být ve své kritice především konstruktivní a taktní.

Tyto požadavky však většinou tutoři velice podceňují. Mnohdy svůj postoj zdůvodňují tím, že jde přece o dospělé, tak proč se jim takto podbízet. Když chtějí dospělí studovat, tak at' studují. Tento prístup je patrný i v některých reakcích na korespondenční úkoly. Neznalost specifik dospělých účastníků vzdělávání, neochota měnit zažité didaktické postupy (někdy až andragogický amatérismus), nechut' zvyšovat 
svoje technické kompetence ( $\mathrm{k}$ řizení e-learningového učení), to vše může být značným limitem e-learningu.

Naše zkušenosti z pedagogického vzdělávání vypovídají především o podceňování evalvačního př́stupu ke studujícím a adekvátní zpětné vazby při reakcích tutorů na samostatné práce a úkoly.

\section{Podceňování aktivit celoživotního vzdělávání a absence morální podpory tutorů}

Vysokoškolské instituce řeší v posledních letech tak naléhavé finanční, existenční, personální a další problémy, že jim žel nezbývá vůbec prostor $\mathrm{k}$ tomu, aby se zabývaly problematikou realizace programů celoživotního vzdělávání, e-learningem, př́pravou a vzděláváním tutorů a především morálním oceňováním jejich práce.

Podle názoru Normana Longwortha a W. Keith Daviese (1996, s. 15) by ale především ve scénáŕi celoživotního vzdělávání potřebovaly vysoké školy kompletně přehodnotit své cíle a priority, zejména vstupní požadavky, metody práce, hodnocení a kvalifikační struktury. Studenti každého věku by měli mít šanci vstoupit do jejich kurzů a využívat rozmanité metody vzdělávání. Celoživotní vzdělávání podle zmíněných autorů zpochybňuje tradiční role univerzit jako schránky intelektuálního kapitálu národa a jako centra pro výzkum a jedinečnou kvalitu. To postačuje pro př́pravu mnoha vysokoškolsky vzdělaných jedinců, ale radikální změna, která nevyhnutelně přichází, očekává více. Umožní existenci jenom těm institucím, které na ni budou vhodně připraveny a náležitě vybaveny pro poskytování „mnohopř́ístupového“ vzdělávání širokému spektru zájemců.

Bez morální podpory, oceňování participace vysokoškolských učitelů na aktivitách CŽV ze strany vysokoškolské instituce a bez náležité príípravy a systematického vzdělávání tutorů není možné dle našeho názoru v současných podmínkách tyto vize naplňovat.

\section{Závěr}

Ze všeho, co jsme uvedli, je zřejmé, že e-learning disponuje značným potenciálem, který lze nepochybně maximálně využít právě $\mathrm{v}$ dalším vzdělávání učitelů. To předpokládá získávání takových znalostí, dovedností a postojů, které jsou úzce spojené s učitelskou praxí a řešením výchovných problémů. Mají-li studující možnost využívat v procesu učení didakticky zpracované a náležitě vizualizované učivo propojené s multimediálně prezentovanými skutečnými nebo simulovanými situacemi z praxe, lze předpokládat zvýšenou účinnost jejich učení. Čím více jsou totiž v tomto vzdělávání účastníci do procesu studia zapojeni, čím více funkční multimediální podpory mohou využívat a čím hlouběji je jejich proces učení řízený tutorem, navigovaný prostřednictvím zpětné vazby a usměrňovaný efektivní komunikací, tím více jsou motivování se na procesu vzdělávání aktivně podílet a díky tomu dosahovat požadované výstupy z učení.

Pokud je vzdělávání učitelů připravované jako distanční s podporou e-learningu, je žádoucí tuto podporu neustále rozšiřovat ve prospěch vy̌šší aktivizace, multimedializace (studijních opor i celých kurzů) a ve směru prohlubování vícesměrné komunikace. Má-li být totiž toto vzdělávání skutečně plnohodnotné, kvalitní, je nezbytné vytvořit těmto studujícím vhodné podmínky, nabídnout jim takovou podporu a metody vzdělávání, které mohou minimalizovat jejich studijní bariéry. Otázka, proč nedokážeme v kontextu našeho pedagogického vzdělávání ve stávajících podmínkách zmíněný potenciál 
a především multimediálnost e-learningu náležitě a plnohodnotně využít, by rozhodně zasluhovala hlubší analýzu a zkoumání.

$\mathrm{Na}$ všechny uvedené požadavky, ale i na změny reflektující společenské poslání vysokých škol při realizaci celoživotního vzdělávání musí být připraveni především vzdělavatelé, protože od profesionality jejich práce závisí a bude záviset jak ,příliv klientư“, tak i př́sun pro vysokoškolské instituce nezbytných finančních prostředků. Pojmy jako konkurence, zákon nabídky a poptávky, kvalita, servis služeb, spokojenost klienta se proto pomalu ale jistě promítají do požadavků na znalosti a dovednosti vysokoškolského učitele.

Moderní vzdělávací technologie, především distanční vzdělávání a e-learning kladou na vzdělavatele neobvykle vysoké pedagogické i technické nároky a vyžadují speciální kompetence, adaptabilnost, flexibilitu a především kvalitu vysokoškolských učitelů, kteř́ jsou klíčovými aktéry při zprostředkovávání vzdělávání nebo řízení učení dospělých studujících. Proto je nezbytné je pro jejich vzdělávací působení systematicky připravovat, silně motivovat a náležitě oceňovat.

\section{Literatura}

Barešová, E. (2003). E-learning ve vzdělávání dospělých. Praha: VOX.

Bočková, V. (2002). Vzdělávání - průvodní jev života. Olomouc: Univerzita Palackého $\mathrm{v}$ Olomouci.

Burgerová, J. (2012). Vybrané aspekty kvality vzdelávania na PU. In Komplexnost' a integrita v predprimárnej, primárnej a špeciálnej edukácii [CD ROM]. Prešov: PF PU. Eger, L. (2002). Př́prava tutorů pro distanční výuku s využitím online formy studia. Plzeň: Západočeská univerzita v Plzni.

Egerová, D. (2012). E-learning jako možný nástroj vzdělávání a rozvoje pracovníků. Plzeň: Západočeská univerzita v Plzni.

Hartl, P. (1999). Kompendium pedagogické psychologie dospělých. Praha: Karolinum.

Hughes, J. (Ed). (2009). TACCLE. Teachers Aids on Creating Content for Learning Environments. The E-learning Handbook for Classroom Teachers. Brussels: GO! Onderwijs van de Vlaamse Gemeenschap.

Kopecký, K. (2006). E-learning (nejen) pro pedagogy. Olomouc: Hanex.

Longworth, N., \& Davies, W. K. (1996). Lifelong Learning. New vision, new implications, new roles for people, organizations, nations and communities in the 21st century. London: Kogan Page.

Mareš, J. (1998). Styly učeni žáků a studentů. Praha: Portál.

Moore, J. R. (1988). Guidelines Concerning Adult Learning. Journal of Staff Development, 9 (3).

Palán, Z. (2002). Lidské zdroje. Výkladový slovník. Praha: Academia.

Petřková, A. (2000). Psychologické základy vzdělávání dospělých. Olomouc: Univerzita Palackého v Olomouci.

Prensky, M. (2001). Digital Natives, Digital Immigrants. Horizon, MCB University Press, 9 (5). Dostupné z WWW: http://www.marcprensky.com/writing/Prensky\%20\%20Digital\%20Natives,\%20Digital\%20Immigrants\%20-\%20Part1.pdf

Prusáková, V. (2000). Metodika vzdelávania dospelých. Olomouc: Univerzita Palackého. 
Šimonová, I., \& Poulová, P. (2012). E-learning a možnosti jeho individualizace. In Sbornik príspěvků z konference a soutěže eLearning 2012. Hradec Králové (s. 132-137). Gaudeamus.

Švejda, G. (2007). Didaktické evaluace v procesu on-line vzdělávání. In eLearning 2007. Sborník př́spěvků z konference a soutěž eLearning 2007 (s. 461-464). Hradec Králové: Gaudeamus.

Vyhláška č. 317/2005 Sb., o dalším vzdělávání pedagogických pracovníků, akreditační komisi a kariérním systému pedagogických pracovníků. (2005). Dostupné z: http://www.msmt.cz/ministerstvo/vyhlaska-c-317-2005-sb-2

Zákon č. 111/1998 Sb., o vysokých školách (1998). Dostupné z: http://www.msmt.cz/vyzkum-a-vyvoj/zakon-c-111-1998-sb-o-vysokych-skolach Zlámalová, H., \& Bednaříková, I. (2007). Tutorská práce v elektronickém kurzu dalšího vzdělávání dospělých. In Sborník př̉spěvki̊ z konference a soutěže eLearning 2007 (s. 490-498). Hradec Králové: Gaudeamus.

Zlámalová, H. (2012). Kvalita eLearningu jako součásti distančního vzdělávání. In Kapounová, J. et al., Př́stupy k evaluaci eLearningu (s. 35-54). Ostrava: Ostravská univerzita v Ostravě. 